\section{'Byron Beauty', An Ornamental Passion Vine for the Temperate Zone}

\author{
R.J. Knight, Jr.
}

Subtropical Horticulture Research Station, Agricultural Research Service, U.S. Department of Agriculture, Miami, FL 33158

\section{J.A. Payne}

Southeastern Fruit and Tree Nut Research Laboratory, Agricultural Research Service, Byron, GA 31008

\section{R.J. Schnell}

Subtropical Horticulture Research Station, Agricultural Research Service, U.S. Department of Agriculture, Miami, FL 33158

\section{A.A. Amis \\ Southeastern Fruit and Tree Nut Research Laboratory, Agricultural Research Service, Byron, GA 31008}

Additional index words. Passiflora incarnata $\times$ P. edulis, conservation biology, hummingbird, butterflies, cold tolerant

Plants of ornamental value that provide nectar for butterflies, bees, and hummingbirds and crucial forage for caterpillars of several native butterflies have a place in the home garden. A new vine of hybrid origin that promises to be well adapted to warm temperatezone climates is 'Byron Beauty', an amphiploid derived from crossing Passiflora incarnata L. X P. edulis Sims. This plant has no special needs other than a well-drained soil of reasonable fertility and a support (fence, trellis, or tree) on which to grow. It does not spread by seed, but is easily propagated during the growing season from one-node cuttings placed in intermittent mist in a warm greenhouse.

\section{Origin}

'Byron Beauty' (M34366) is a seedling from a population of tetraploid hybrid passion vines produced in Miami in 1989 from a cross of selection M30175F (seed parent) $\mathrm{x}$ M28346A(Fig. 1). The released germplasm is a single clone that is self-incompatible and does not bear fruit when grown in isolation from other tetraploid passion vines.

\section{Description}

'Byron Beauty' passion vine is vigorous, growing $\geq 5 \mathrm{~m}$ tall on a congenial planting site. Like its $P$. incarnata parent, 'Byron Beauty' can resprout from below ground after a series of killing frosts, so it is reliably winter hardy in the southeastern states as far north as central Georgia. The leaves are trilobed, strongly denticulate, and range from 13 to $24.5 \mathrm{~cm}$ long $\times$ 15.1 to $25.3 \mathrm{~cm}$ wide. The flower is a typical

Received for publication 17 Dec. 1994. Accepted for publication 6 Apr. 1995. The cost of publishing this paper was defrayed in part by the payment of page charges. Under postal regulations, this paper therefore must be hereby marked advertisement solely to indicate this fact. passionflower in structure but, probably because of its ploidy, is larger than either parent, ranging from 8.5 to $9.6 \mathrm{~cm}$ in diameter. The color pattern of $P$. edulis prevails in this clone's flowers; they have an inner disk of deep purplish-blue petals and filaments surrounded by an outer margin of lighter color (Fig. 2). A unique character of 'Byron Beauty' that separates it from most of its siblings is the crinkled

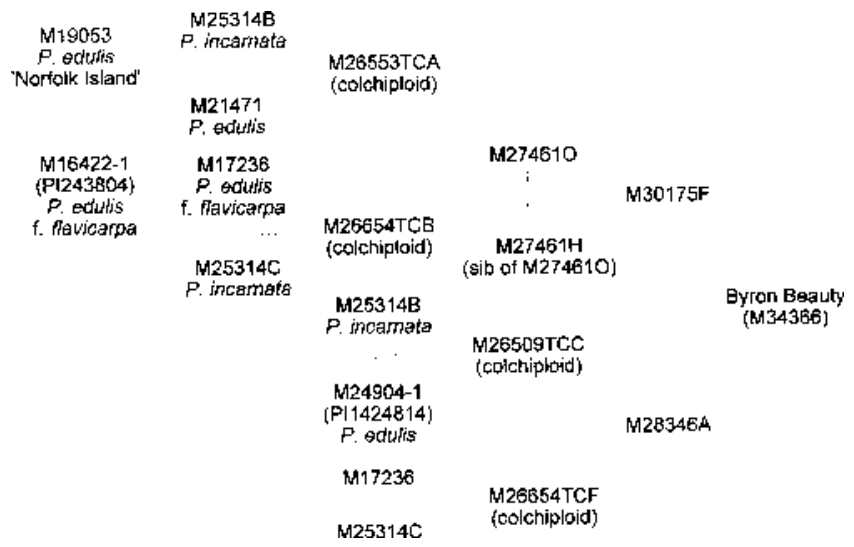

Fig. 1. Pedigree of Passiflora 'Byron Beauty'

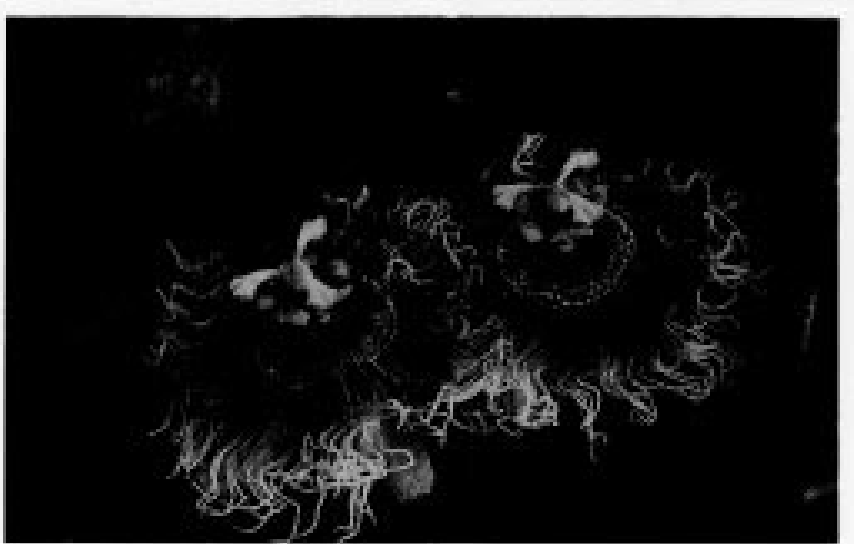

Fig. 2. Flowers of ornamental passion vine 'Byron Beauty'. fringe of white marking the outer edge of an otherwise deep purplish-blue filamentous corona, which makes a vine in full bloom a spectacular sight.

Hummingbirds, bees, and butterflies are attracted to the flowers, which open near midday and remain open until dark. Flowers normally are open just 1 day, but toward the end of the growing season, when nights are cool, flowers may remain open a second day, thus adding to the floral display. This tetraploid passion vine is a preferred host for two butterflies that occur widely in the southeastern states, the variegated fritillary [Euptoieta claudia (Cramer)] and the Gulf fritillary [Agraulis vanillae (L.)]. Farther south, the vine is also a host for the zebra butterfly [Heliconius charitonius (L.)]. Thus, 'Byron Beauty' provides needed and often scarce larval host habitat for nurturing and maintaining populations of these butterflies. The vigor of the vine is such that sizable populations of caterpillars feeding on the leaves do not affect growth and flowering in any obvious way. Nectar from the flowers also provides nourishment for the ruby-throated hummingbird [Archilochus colubris (L.)].

\section{Availability}

A list of nurseries that currently can provide a limited number of cuttings of Passiflora 'Byron Beauty' is available from A.A.A., Southeastern Fruit and Tree Nut Research Laboratory, 111 Dunbar Rd., Byron, GA 31008. 